\title{
Features of Critical Thinking of Individual Entrepreneurs With Different Levels of Self-Regulation
}

\author{
Galina A. Molokhina ${ }^{1}$ (D), Vlada I. Pishchik ${ }^{2^{*}}$ (D) Arkadiy Fomin ${ }^{3}$ (D)
}

\author{
${ }^{1}$ Synergy University, Faculty of E-Learning, Moscow, Russian Federation, e-mail: molokhina@yandex.ru \\ 2Don State Technical University, Department of Educational Psychology and Organizational Psychology, Rostov-on-Don, \\ Russian Federation, e-mail: vladaph@yandex.ru \\ ${ }^{3}$ Driving school, Rostov-on-Don, Russian Federation, e-mail: apfomin78@gmail.com
}

\begin{abstract}
In the crisis conditions of entrepreneurs business functioning in Russian, it is important to develop critical thinking in conjunction with the skills of self-regulation of behavior. It is assumed that entrepreneurs with different styles of selfregulation differ in the level of critical thinking, and there is also a relationship between the styles of self-regulation and the level of critical thinking. The theoretical basis of the study is the idea of the relationship between the degree of formation of individual self-regulation and the productivity of performing various types of professional activities. The sample of the study consisted of 140 individual entrepreneurs engaged in entrepreneurial activity for more than two years, aged from 30 to 50 years. We used techniques to analyze the style of self-regulation of behavior, volitional self-regulation, critical thinking and mental abilities. The study allowed us to expand the understanding of the relationship between critical thinking and self-regulation, to reveal the content aspects of critical thinking of entrepreneurs with different levels of self-regulation of behavior. We found out that in the group of entrepreneurs with a high level of self-regulation of behavior, there is a high level of volitional self-regulation, perseverance, self-control, information processing skills and critical thinking skills. We came to conclusion that there are differences at the content and semantic level among entrepreneurs, differentiated by the type of self-regulation. For entrepreneurs with a low level of self-regulation, it is planned to conduct a program for the development of critical thinking.
\end{abstract}

Keywords: critical thinking, self-regulation, individual entrepreneurship, development program.

\section{Introduction}

The study updates research in the sphere of critical thinking. The participants of the World Economic Forum in Davos in 2020 put critical thinking on the second place in the list of skills in demand in the labor market. The focus of our interest was to understand the place of critical thinking in the activities of an individual entrepreneur. The developed critical thinking technologies (Smith, 2011; Zair-Bek and Mushtavinskaya, 2011; Al-Shalabi, 2015; Tang, Vezzani and Eriksson, 2020) are used for collaboration and developmental learning. From the theoretical point of view, the study of the problem of the critical thinking development in individual entrepreneurs with different styles of self-regulation confirms the works of scientists, clarifies scientific ideas about the social and psychological properties of the individual entrepreneur's personality. These features are manifested in a complex of relationships, self-esteem, motivation, and interaction with the economic side of activity (Zair-Bek and Mushtavinskaya, 2011). The researchers emphasize that critical thinking reflects a system of mental states, properties and processes that are aimed at producing an assessment. Critical thinking helps the individual entrepreneur think constructively, based on the four main principles that characterize this process: the need to identify and refute assumptions; verify facts, logical consistency; take into account contextual information; explore alternatives. Each of the principles is considered a thinking skill, and it takes practice and time to master them.

There are two different approaches to understanding of critical thinking. Critical thinking is a type of intellectual activity characterized by a high level of comprehension, perception, objectivity to the information received and the surrounding world (Klooster, 2002). Klooster D. J. speaks about five aspects, which differentiate critical thinking from the other types: it is completely independent; information creates "Corresponding author: vladaph@yandex.ru 
a motivating factor for it; it arises from a question and determining the problem; it is a deep social thinking which is based on the intellectual abilities, the ability to argue (Klooster, 2002). Many modern researchers of critical thinking (Smith, 2011; Zair-Bek and Mushtavinskaya, 2011; Halpern, 2013; Robert and Petersen, 2013; Davies and Barnett, 2015; Bowell, Cowan and Kemp, 2019; Yaldız and Bailey, 2019; Dekker, 2020) understand the concept of "critical thinking" as a set of skills, abilities and personality traits that determine the highest level of research activity. Halpern D. F. describes critical thinking as the usage of cognitive strategies and techniques that increase the possibility of obtaining the desirable result (Halpern, 2013) characterizes it as the use of cognitive strategies and techniques that increase the likelihood of obtaining the desired outcome. This definition indicates that critical thinking is controlled, grounded, and purposeful.

It her theory of thinking styles Belousova A. K. describes the critical style of thinking as the performance of a selective function, which is expressed, first of all, in the ability of a person to see weaknesses, mistakes, and various shortcomings (Belousova and Pishchik, 2015). Critical thinking is used when it is necessary to solve a difficult problem, formulate conclusions, interpret the results, make an assessment and make a decision. A thinking person uses sound and effective skills that are relevant in a particular situation to solve a particular problem. Critical thinking consists of evaluating the thinking process, reasoning, which are the stages of the final conclusion and ultimately lead to a decision making (Zagashev and Zair-Bek, 2003; Yaldız and Bailey, 2019).

Researchers claim that critical thinking is evaluative and reflexive logical thinking that is based on personal experience and reliable facts. For it, knowledge is not an end point, but a starting point, reasoned and logical (Zagashev and Zair-Bek, 2003; Szenes and Tilakaratna, 2021). The teaching, which is focused on the formation of thinking skills, provides not only the assimilation of information, but also its application in the process of professional activity, comparison with the experience gained.

Halpern D. F. highlights the skills of a critical thinker, including analysis of the situation and conclusions, formulation, promotion and development of a hypothesis, search for solutions, activation of acquired knowledge and causal relationships, analysis of significance, comparisons, matching, use of argumentation, assessment of its reliability, generalization, study of other people's points of view (Halpern, 2013). Thus, critical thinking allows you to extract information from memory; interpret the information received, the situation, give examples, compare and generalize; apply your knowledge, skills and abilities in practice; analyze information, differentiate and correlate; evaluate information and develop your own criteria; create something new (Fedorov, 2007; Tang, Vezzani and Eriksson, 2020).

Zair-Bek S. I. for the formation of critical thinking, suggested an algorithm, which is based on the search for answers to the questions: 1 . Setting a goal, choosing the only correct solution, as well as evaluating and verifying the accuracy of the information received. 2. Search for additional information. 3. Applying critical thinking skills. 4. Resolving issues and problems (Zair-Bek and Mushtavinskaya, 2011). Active thinking processes allow you to find the essence of the phenomenon that will satisfy your interest. The processes of critical thinking consist of curiosity, openness, lability, trusting attitude, honesty in judgments, and the desire to search for results. Critical thinking is based on the individual experience and personality qualities of the subject (Popkov, Korzhuev and Ryazanova, 2001; Zair-Bek and Mushtavinskaya, 2011).

The above-mentioned thoughts actualize the problem of developing the critical thinking of individual entrepreneurs to optimize their activities. There are technologies for developing critical thinking that can, with a certain degree of approximation, be reduced to three phases of training (Zair-Bek and Mushtavinskaya, 2011; Swart, 2017; Kitsantas, Baylor and Hiller, 2019; Tang, Vezzani and Eriksson, 2020). The first phase is a challenge, motivation. Its main purpose is to arouse interest in information, to focus attention on the raised topic. At this stage, information is collected, questions are raised and answers are given. The second phase is comprehension. It is characterized by the submission of new information. Its source can be an individual entrepreneur. In the second phase, a filter is applied to the previously raised questions, most of which are filtered out and the subject matter of the conversation appears. The final phase is reflection. Here the data is analyzed, opinions are exchanged, and the point of view is expressed. At this stage, we combine our own experience with new knowledge.

Techniques allow you to develop critical thinking skills. Critical thinking skills include providing an understanding of what thinking ability an individual entrepreneur needs to have in order to work effectively. Entrepreneurs should identify the causes of phenomena and events, learn the correct formulation of questions, the art of argumentation, as well as the ranking of information. The need for its development for an individual entrepreneur is to increase communication links. Successful entrepreneurial activity depends on the ability to analyze information, apply it to work, using personal potential and accumulated experience (Korzhuev, Popkov and Ryazanova, 2001; Peschl, Deng and Larson, 2020).

For effective activity, an entrepreneur must have the following qualities: readiness for planning (ordering of thoughts, consistency of presentation of the essence speaks of confidence), flexibility 
(perception of other people's thoughts and ideas), perseverance (when faced with a difficult task, you do not need to postpone it for later), willingness to correct your mistakes (take note of incorrectly drawn conclusions), awareness (allow you to track the course of your own reasoning), search for compromise solutions (the decisions should be perceived by other people) (Zagashev and Zair-Bek, 2003; Kerr, Kerr and $\mathrm{Xu}, 2017)$. These qualities are related to the self-regulation of an entrepreneur.

Self-regulation in Russian psychology is understood as integrative mental processes that ensure the self-organization of a person's mental activity as a subject of actions (Morossanova, 2003; Morossanova, 2010). It was found out that professionals with a high level of self-regulation and the same level of development of all regulatory properties easier master new types of activities and more often achieve high efficiency in the professional sphere, as well as implement strategies of independence in decisionmaking. Kitsantas Baylor and Hiller (2019) define self-regulation as a cyclical process in which learners use external feedback to evaluate and adjust their learning strategies. That is why it is so important to take into account self-regulation when studying critical thinking. Kamgar and Jadidi established indirect relationship between critical thinking and the components of self-regulation (implementation and formulation of the plan, search and evaluation of factors) of students (Kamgar and Jadidi, 2016). With the help of critical thinking, one can achieve the set goals, process a large amount of information, work correctly and confidently with people, colleagues and subordinates, develop your own opinion, comprehend the gained experience, engage in self-education and build constructive relationships with others (Dwyer, 2017). The technology is based on the understanding of the acquired knowledge.

Thus, critical thinking is an important component, without which it is difficult to build constructive correct and effective activities. Today, the problem of developing critical thinking is incredibly relevant, as the era of the information society encourages people to independently search for the necessary information and interpret it logically. Scientists have come to the conclusion that a person who does not develop critical thinking (meaningful, objective, analyzing) is not able to make independent decisions, conduct in-depth analysis, search, apply the accumulated experience in the course of activities, draw conclusions and interpret the results. For an individual entrepreneur, it is important to think critically. This helps us achieve our goals, solve complex problems and solve economic issues. In this regard, the purpose of our research is to determine the features of critical thinking of entrepreneurs with different levels of self-regulation, who are involved in entrepreneurial activity in the Southern federal district on the territory of the Russian federation.

\section{Materials and Methods}

The study sample consisted of individual entrepreneurs who have been doing business for more than two years with varying degrees of economic success and work experience, aged from 30 to 50 years, in the number of 140 people, 85 men and 55 women. All entrepreneurs participated in the survey voluntarily. The survey was conducted via the Internet.

We used in the study: the questionnaire "The style of self-regulation of behavior by Morossanova" (Spiridonov, 1980); the test-questionnaire "The study of volitional self-regulation" by A. V. Zverkov and E. V. Eidman (Surkova, 2008); the test of critical thinking by L. Starkey (Starkey, 2004) (adapted by Lutsenko, 2014); The Wonderlic Intelligence Test (WIT) by E. F. Wonderlic and V. N. Buzin (Surkova, 2008); statistical methods: correlation analysis, Mann-Whitney U test.

\section{The description of the research methods}

The questionnaire "Style of self-regulation of behavior" consists of forty-six questions to which the following answers must be given: "True", "Perhaps true", "Perhaps not-true", "Not-true". The results are evaluated in accordance with the coincidences with the regulatory scales "Planning", "Modeling", "Programming", "Evaluation of results", "Flexibility", "Independence" and "General level of self-regulation". For each match, the test subject gets one point.

By the number of points scored, you can judge the results (low, medium, high level). For example, the scale "General level of self-regulation" evaluates the degree of meaningful self-regulation of activity in individual entrepreneurs. The subjects who scored a large number of points (a high indicator) are flexible, independent individuals who respond adequately to the changed conditions. They achieve their goal consciously. Entrepreneurs with a high level of self-regulation are able to change attitudes in order to achieve the goal. This allows him to achieve success in any field of activity and feel confident in difficult situations.

The low level of self-regulation in an individual entrepreneur indicates that the subject is not flexible 
enough, he is not able to consciously plan and program his own behavior to achieve the goal. People with a low self-regulation depend on the opinions of others and on the circumstances or difficult situation. Success in mastering a new activity depends on the ability to regulate your own behavior and think critically.

The test questionnaire "Study of volitional self-regulation" consists of thirty questions-statements to which you need to answer "True" or "False", and put a "+" or " - "sign in front of each question, which corresponds to a positive or negative answer. The questions are simple, so they will not cause difficulties in answering. The level of volitional self-regulation is calculated, taking into account the coincidences in the general scale (B) and the scales "Perseverance" $(\mathrm{H})$ and "Self-control" (C). High scores in all three scales indicate that an individual entrepreneur achieves his goals, is emotionally stable, self-confident, and is characterized by innovation and radicalism. The test subjects who got high scores are able to regulate emotions, be flexible, inventive, eliminate internal tension in difficult situations, and respond adequately to any circumstances. Such people are alien to the fear of the unknown, which allows them to achieve success even in an unfamiliar business. Low indicators are the opposite pole. The test subjects with low scores are insecure, emotional, sensitive, vulnerable, and have difficulty coping with fear, overcoming obstacles, and striving for innovation. These qualities prevent us from achieving our goals and success in the professional sphere and in life. The test results will help to correct the behavior and way of thinking of entrepreneurs who scored a small number of points, using the developed program.

The L. Starkey Critical Thinking Test consists of thirty questions. The test taker should mark the most appropriate answers, in his opinion. This questionnaire meets the psychometric requirements of reliability, is objective and is aimed at the adult age group of both sexes. The test is maximally adapted for use in modern society. You can use it to test your propensity for critical thinking. According to researchers A. V. Fedorov, D. G. Myers, D. F. Halpern, J. Berglund critical thinking explores assumptions, evaluates data, and draws conclusions, builds logical conclusions, creates consistent logical models and chains, and makes reasoned decisions (Fedorov, 2007; Myers, 2010; Halpern, 2013; Berglund, 2020).

The results of the $\mathrm{L}$. Starkey test can be interpreted taking into account the accepted standards of testing: they can be divided into very high, high, medium, and very low levels of critical thinking. There are obstacles on the way of critical thinking. The first of them are emotions that prevent you from thinking rationally.

The Wonderlic Intelligence Test (WIT) consists of fifty questions. The main purpose of the questionnaire is to determine the level of intellectual abilities. This technique belongs to the category of tests of mental abilities $(\mathrm{IQ})$, which indicate the general intellectual development of an individual and allows you to diagnose such parameters of intelligence as the ability to generalize and analyze, flexibility of thinking, speed and accuracy of perception of material, the choice of the optimal strategy, i.e. parameters that ensure effective processing of information. The questions are easy to understand, and the correct answers are related to the concentration of attention and the correct reading of the question. Some of the questions in the test did not have an answer to the choice, the test taker had to solve the problem himself, without any prompts. It is necessary to start the test in a cheerful state, which will allow you to cope with the questionnaire in a short time. The results are calculated according to the points system: one point is for each correct answer. Thus, the more points an individual entrepreneur scored, the higher his level of intellectual abilities. However, the authors of the test emphasize that if the test subject scores an insufficient number of points, that is, shows a low result, it will not indicate psychological professional unfitness. The reason for the low result may be fatigue, incorrect interpretation of the question. That is why it is possible to judge the intellectual abilities objectively only after a series of tests that the entrepreneur will pass. The test is given no more than fifteen minutes to complete, which complicates the task for the test subject.

A low test score (16 points or less) also indicates that an individual entrepreneur may experience some difficulties in professional activity and training. A high result (24 points or more) indicates a sufficient level of intellectual abilities that allows an individual entrepreneur to fulfill and master a wide range of responsibilities in any profession. Specialists with high intelligence quickly achieve results and success in creative activities.

We put forward the following hypotheses: $\mathrm{H} 1$ - we assume that it is possible to differentiate groups by the level of self-regulation; $\mathrm{H} 2$ - we assume that entrepreneurs with a high level of self-regulation also have high indicators of critical thinking; $\mathrm{H} 3$ - we assume that it is possible to find a stable relationship between the styles of self-regulation and the level of critical thinking in individual entrepreneurs.

To test the hypotheses we used statistical methods. Initially, the normality of the distribution of the trait within the sample was checked. Since the distribution of the trait was different from the normal one, we used the Spearman rank correlation and the nonparametric Mann-Whitney $U$ test for further calculations. 


\section{Results}

Group differentiation of entrepreneurs was carried out on the bases of diagnoses data of behavior self-regulation. High indicators on the scale of "General level of self-regulation" indicate that individual entrepreneurs are quite independent, adequately and flexibly react to changing of working and living conditions. They are able to put forward and achieve goals consciously. The motivation of an entrepreneur with a high level of self-regulation is compensated by character traits, personal qualities that prevent him from moving towards the goal. The higher the level of self-regulation of the respondent, the easier he copes with a new type of activity, adapts better in an unfamiliar environment, and achieves goals faster. The results are presented in Table 1.

Table 1

Indicators of self-regulation in groups

\begin{tabular}{|c|c|c|c|c|c|c|c|c|c|c|}
\hline \multirow[b]{2}{*}{ Scales } & \multicolumn{2}{|c|}{$\mathrm{N}$} & \multicolumn{2}{|c|}{ Minimum } & \multicolumn{2}{|c|}{ Maximum } & \multicolumn{2}{|c|}{ Mean } & \multicolumn{2}{|c|}{ Std. Deviation } \\
\hline & 1 & 2 & 1 & 2 & 1 & 2 & 1 & 2 & 1 & 2 \\
\hline General level of self-regulation style & 54 & 86 & 33,00 & 21,00 & 39,00 & 32,00 & 35,00 & 27,34 & 1,88 & 3,65 \\
\hline Planning & 54 & 86 & 2,00 & 1,00 & 9,00 & 9,00 & 5,92 & 5,53 & 2,40 & 2,40 \\
\hline Modelling & 54 & 86 & 2,00 & 1,00 & 8,00 & 9,00 & 5,35 & 5,26 & 2,06 & 2,55 \\
\hline Programming & 54 & 86 & 3,00 & 4,00 & 9,00 & 9,00 & 7,07 & 7,26 & 1,94 & 1,56 \\
\hline Results evaluation & 54 & 86 & 2,00 & 2,00 & 9,00 & 9,00 & 5,85 & 5,53 & 2,31 & 2,38 \\
\hline Flexibility & 54 & 86 & 3,00 & 4,00 & 9,00 & 9,00 & 7,28 & 7,23 & 1,89 & 1,58 \\
\hline Independence & 54 & 86 & 4,00 & 4,00 & 9,00 & 9,00 & 7,50 & 7,23 & 1,60 & 1,39 \\
\hline
\end{tabular}

Accepted abbreviations: 1 - a group with high self-regulation; 2 - a group with low self-regulation.

The test subjects with low levels of self-regulation depend on the situation and surrounding people, need conscious programming and planning of their own behavior. New types of activities for individual entrepreneurs with a low level of self-regulation cause difficulties, and the results are directly dependent on working conditions. The categories of self-regulation were also analyzed: planning, modeling, programming, evaluation of results, flexibility, independence (Table 2).

Table 2

The results of the study of behavior self-regulation

\begin{tabular}{llllll}
\hline \multicolumn{1}{c}{ Indicators } & \multicolumn{1}{c}{$\begin{array}{c}\text { Average point in } \\
\text { group 1 }\end{array}$} & \multicolumn{1}{c}{$\begin{array}{c}\text { Average point in } \\
\text { group 2 }\end{array}$} & U & p \\
\hline General level of behavior self-regulation & 35 & 27,35 & 163,2 & 0,00 \\
Planning & 5,93 & 4,54 & 138,0 & 0,05 \\
Modelling & 5,36 & 4,27 & - & \\
Programming & 7,07 & 7,27 & - & \\
Results evaluation & 5,86 & 5,54 & - & \\
Flexibility & 7,29 & 6,23 & - & \\
Independence & 7,50 & 6,23 & 0,05 & \\
\hline
\end{tabular}

According to the calculations, the indicators of the general level of self-regulation of behavior are higher in the first group, in the second group they are low. The calculation of the criterion for the significance of differences showed that these differences are statistically significant.

After that, we investigated volitional self-regulation, which is associated with general self-regulation. High indicators of volitional self-regulation of respondents on the three scales "General self-regulation", "Perseverance", "Self-control" indicate emotional maturity, activity, stability, and realistic views. Individual entrepreneurs with a high level of volitional self-regulation have a developed sense of their own duty, reflect well their personal motives, are able to properly distribute their forces, keep everything under control. They are highly efficient, strive to fulfill their tasks, overcome any obstacles, and respect social norms. High indicators indicate emotional stability, self-confidence, a propensity for innovation, and a 
desire for self-control.

Low indicators of respondents on all three scales indicate sensitivity, emotional instability, vulnerability, and self-doubt. Individual entrepreneurs with low indicators have low reflexivity, a reduced background of activity, impulsivity, high lability, and self-doubt. All this leads to inconsistency of actions, resentment, inner feelings, inability to overcome conflicts. Low indicators may also indicate the inability to adequately respond to situations, interact with people, indicate violations of personality traits. Table 3 shows the results on the indicators of volitional self-regulation of entrepreneurs.

Table 3

The results of the study of volitional self-regulation

\begin{tabular}{|c|c|c|c|c|c|c|c|c|c|c|c|}
\hline \multirow{2}{*}{ Scales } & \multirow{2}{*}{ Groups } & \multicolumn{2}{|c|}{$\mathrm{N}$} & \multicolumn{2}{|c|}{ Minimum } & \multicolumn{2}{|c|}{ Maximum } & \multicolumn{2}{|c|}{ Mean } & \multicolumn{2}{|c|}{ Std. Deviation } \\
\hline & & 1 & 2 & 1 & 2 & 1 & 2 & 1 & 2 & 1 & 2 \\
\hline \multicolumn{2}{|c|}{ Volitional self-regulation } & 54 & 86 & 13,00 & 11,00 & 23,00 & 24,00 & 18,85 & 18,57 & 3,15 & 3,31 \\
\hline \multicolumn{2}{|c|}{ Perseverance } & 54 & 86 & 9,00 & 6,00 & 14,00 & 14,00 & 11,78 & 9,34 & 1,71 & 1,97 \\
\hline \multicolumn{2}{|c|}{ Self-control } & 54 & 86 & 4,00 & 6,00 & 12,00 & 12,00 & 9,21 & 8,84 & 2,11 & 1,31 \\
\hline
\end{tabular}

The comparative analysis showed that the average values of the indicators of the level of volitional self-regulation are higher in the first group, as well as perseverance, self-control. There is a high significance of differences in the level of perseverance scale (Table 4).

Table 4

Comparative analysis of volitional self-regulation

\begin{tabular}{lcccc}
\hline \multicolumn{1}{c}{ Scale } & $\begin{array}{c}\text { Average point in } \\
\text { group 1 }\end{array}$ & $\begin{array}{c}\text { Average point in } \\
\text { group 2 }\end{array}$ & U & p \\
\hline Level of volitional self-regulation & 18,86 & 18,58 & - & \\
Perseverance & 11,79 & 9,35 & 64,50 & 0,001 \\
Self-control & 9,21 & 8,85 & - & \\
\hline
\end{tabular}

Thus, the $\mathrm{H} 1$ hypothesis was confirmed and the group was divided into 2 parts: respondents with high and low self-regulation indicators.

Next, we determined the level of critical thinking of the entrepreneurs of the two groups. The high results of the respondents on the test indicate that these individual entrepreneurs have well-developed logical thinking, induction, deduction, and reflection. An individual entrepreneur can well control his emotions. These emotions affect the making of responsible decisions; analyze information, check it for reliability, recognize manipulation from the outside, advertising, propaganda, detect cause and effect, allow and recognize the limitations of your own thought process, take into account and accept other people's opinions, develop the most realistic and optimal solutions in difficult conditions and achieve them. An individual entrepreneur with a high level of critical thinking is an effective professional who makes complex and responsible decisions; quickly adapts to changing environmental conditions. The results were presented in Table 5.

Table 5

Indicators of critical thinking

\begin{tabular}{|c|c|c|c|c|c|c|c|c|c|c|c|}
\hline \multirow{2}{*}{ Scales } & \multirow{2}{*}{ Groups } & \multicolumn{2}{|c|}{$\mathrm{N}$} & \multicolumn{2}{|c|}{ Minimum } & \multicolumn{2}{|c|}{ Maximum } & \multicolumn{2}{|c|}{ Mean } & \multicolumn{2}{|c|}{ Std. Deviation } \\
\hline & & 1 & 2 & 1 & 2 & 1 & 2 & 1 & 2 & 1 & 2 \\
\hline Critical thinking & & 54 & 86 & 15,00 & 10,00 & 26,00 & 25,00 & 20,42 & 17,80 & 3,03 & 3,86 \\
\hline
\end{tabular}
Table 6.

At the next step, we identified the mental abilities of entrepreneurs. The results are presented in 


\section{Table 6}

The results by the level of mental abilities

\begin{tabular}{ccccccccccc}
\hline \multirow{2}{*}{ Scales } & \multicolumn{4}{c}{ Groups } & \multicolumn{1}{c}{ N } & \multicolumn{2}{c}{ Minimum } & \multicolumn{2}{c}{ Maximum } & \multicolumn{2}{c}{ Mean } & \multicolumn{2}{c}{ Std. Deviation } \\
\cline { 2 - 11 } & 1 & 2 & 1 & 2 & 1 & 2 & 1 & 2 & 1 & 2 \\
\hline Level of mental abilities & 54 & 86 & 29,00 & 17,00 & 47,00 & 37,00 & 36,07 & 27,61 & 4,71 & 5,45 \\
\hline
\end{tabular}

High and average results on the questionnaire for the diagnosis of intelligence in individual entrepreneurs may indicate that the respondents have a sufficient level of education in the humanities and exact sciences, the ability to generalize and analyze, flexibility and inertia of thinking, switchability, speed and accuracy of perception, distribution and concentration of attention, spatial imagination, general literacy.

Low results (not revealed) indicate that the individual entrepreneur has an insufficient level of concentration, distribution of attention. The intellectual capabilities of the respondent indicate the level of development of skills and abilities in professional and educational activities that an individual entrepreneur has at a particular time. A low indicator does not indicate the intellectual failure of the respondent, but is an indicator of a certain state.

The level of intellectual abilities of individual entrepreneurs is higher in the first group, these differences are significant (Table 7). The level of critical thinking is higher in the first group, these differences are significant. The $\mathrm{H} 2$ hypothesis was confirmed.

Table 7

Comparative analysis of the results of the level of critical thinking and mental abilities

\begin{tabular}{lllll}
\hline Indicators & $\begin{array}{c}\text { Average points in } \\
\text { group 1 }\end{array}$ & $\begin{array}{c}\text { Average points in } \\
\text { group 2 }\end{array}$ & U & p \\
\hline Level of critical thinking & 20,43 & 17,81 & 110,0 & 0,05 \\
Level of mental abilities & 36,07 & 27,62 & 36,00 & 0,01 \\
\hline
\end{tabular}

The low results on this test indicate that the individual entrepreneur copes with a small number of tasks that require the use of critical thinking. This means that the respondent has insufficiently developed logic, induction and deduction, the ability to recognize unreliable data and search for objective ones, to distinguish manipulation from the outside, to make the right decisions, to be reasoned, as well as to feel the bias of other people. An individual entrepreneur with a low level of critical thinking is not competent enough in an intellectual dispute, and may behave aggressively. Often such people follow the leading of others, become "hostages" of all kinds of beliefs, including sects, as well as bad habits due to the inability to think critically. The development of critical thinking will help to improve the quality of life by changing the emotional state of the respondent.

Our next step was to perform a correlation analysis of the data. The correlation analysis showed that there is a connection between critical thinking and self-regulation and the peculiarities of thinking of individual entrepreneurs with different types of self-regulation.

The results of correlation analysis in Group 1 are presented in Table 8. 
Table 8.

Correlation analysis of indicators in Group 1 of entrepreneurs with a high level of behavior selforganization

\begin{tabular}{lccccccccc}
\hline \multicolumn{1}{c}{ Indicators } & 1 & 2 & 3 & 4 & 5 & 6 & 7 & 8 & 9 \\
\hline 1. Volitional self-regulation & 1 & & & & & & & & \\
2. Persistence & 0,26 & 1 & & & & & & & \\
3. Self-control & $0,81^{\star \star}$ & 0,06 & 1 & & & & & & \\
4. Critical thinking & $0,57^{*}$ & 0,02 & 0,42 & 1 & & & & & \\
5. Mental abilities & 0,47 & $0,67^{\star}$ & 0,39 & 0,32 & 1 & & & & \\
6. Flexibility & 0,52 & $-0,03$ & $0,62^{*}$ & 0,43 & 0,05 & 1 & & & \\
7. Evaluating results & $0,67^{*}$ & 0,09 & 0,51 & $0,57^{\star}$ & 0,05 & 0,47 & 1 & & \\
8. Programming & $0,64^{*}$ & $0,595^{*}$ & $0,59^{\star}$ & $0,73^{\star *}$ & 0,30 & $0,75^{* \star}$ & 0,52 & 1 & \\
9. General level of self-regulation & $-0,16$ & $-0,15$ & $-0,15$ & 0,39 & 0,173 & $-0,28$ & $-0,16$ & 0,02 & 1 \\
\hline
\end{tabular}

${ }^{*} p \leq 0,01,{ }^{*} p \leq 0,05$

In Group 1 the level of critical thinking positively correlates with the indicators of volitional selfregulation $(r=0,57, p=0,034)$, evaluation $(r=0,57, p=0,034)$, programming $(r=0,73, p=0,003)$, there is a positive correlation between the general level of self-regulation and independence $(r=0,59, p=0,028)$, the level of volitional self-regulation positively correlates with self-control $(r=0,81, p=0,000)$, evaluation $(r=0,66, p=0,010)$, programming $(r=0,64, p=0,013)$, mental ability is related to perseverance $(r=0,66$, $p=0,011)$, flexibility is related to self-control $(r=0,62, p=0,019)$.

The results of correlation analysis in Group 2 are presented in Table 9.

Table 9.

Correlation analysis of indicators in Group 2 of entrepreneurs with a high level of behavior selforganization

\begin{tabular}{lccccccccc}
\hline \multicolumn{1}{c}{ Indicators } & 1 & 2 & 3 & 4 & 5 & 6 & 7 & 8 & 9 \\
\hline 1. Volitional self-regulation & 1 & & & & & & & & \\
2. Persistence & $0,45^{\star \star}$ & 1 & & & & & & & \\
3. Self-control & $0,65^{\star \star}$ & $0,51^{\star \star}$ & 1 & & & & & & \\
4. Critical thinking & $0,68^{\star \star}$ & $0,52^{\star \star}$ & $0,43^{\star}$ & 1 & & & & & \\
5. Mental abilities & 0,36 & 0,32 & 0,30 & $0,69^{\star \star}$ & 1 & & & & \\
6. Flexibility & $-0,08$ & 0,03 & $-0,09$ & $-0,08$ & $-0,09$ & 1 & & & \\
7. Evaluating results & 0,12 & 0,07 & 0,12 & 0,24 & 0,18 & 0,10 & 1 & & \\
8. Programming & $-0,29$ & $-0,07$ & $-0,31$ & $-0,32$ & $-0,35$ & 0,10 & 0,09 & 1 & \\
9. General level of self-regulation & 0,35 & 0,09 & 0,35 & $0,47^{\star}$ & $0,52^{* \star}$ & $-0,28$ & 0,10 & $-0,43^{\star}$ & 1 \\
\hline
\end{tabular}

${ }^{*} p \leq 0,01,{ }^{*} p \leq 0,05$

The results of the correlation analysis in Group 2 are presented in Table 9. In Group 2, the following positive correlations were established between critical thinking and the overall level of self-regulation style $(r=0,47, p=0,016)$, volitional self-regulation $(r=0,68, p=0,000)$, persistence $(r=0,52, p=0,006)$, self-control $(r=0,43, p=0,030)$, volitional self-regulation is interrelated with perseverance $(r=0,45, p=$ $0,021)$ and self-control $(r=0,65, p=0,000)$, the overall level of self-regulation is correlated with mental abilities $(r=0,52, p=0,006)$.

According to the results of the correlation analysis, we can conclude that the $\mathrm{H} 3$ hypothesis has been confirmed.

\section{Discussions}

The behavior of an individual entrepreneur depends on the mechanism of self-regulation, selfknowledge, motivation to achieve success in professional activities, as well as on subjective resistance to 
an unfavorable socio-economic environment (Kerr, Kerr and Xu, 2017; Peschl, Deng and Larson, 2020). Self-regulation of the individual is closely related to the level of critical thinking, socio-psychological mechanisms, which are an important criterion for the diagnosis and implementation of the program for the development of critical thinking in an individual entrepreneur. It is consistent with the research results (Morossanova, 2010; Kitsantas, Baylor and Hiller, 2019). The internal motivation of an individual entrepreneur to work, the level of problem solving, the realization of opportunities, and the increase in personal potentials depend on the ability to think critically and self-regulation (Barba-Sánchez and Atienza-Sahuquillo, 2012; Staniewski and Awruk, 2019).

In the course of the study, we identified a tendency to use a certain type of thinking in work and everyday life and a style of self-regulation of behavior. In this regard, there is a confirmation of two hypotheses of the research work about the existence of features of the development of critical thinking in individual entrepreneurs with different styles of self-regulation and the relationship between the styles of self-regulation and the features of critical thinking. This result is combined with the studies (Karabey, 2012; Belousova and Pishchik, 2015), which highlighted the thinking styles of entrepreneurs in combination with decision-making. The analysis of the socio-psychological characteristics of individual entrepreneurs with different styles of self-regulation allows us to identify the typology of a person who can achieve success in professional activities, thanks to critical thinking.

Self-regulation and critical thinking provide an opportunity for an individual entrepreneur to selectively interact with the professional environment, create individual conditions for relationships, show personal meaning, and use the best strategies for independent activity (Kamgar and Jadidi, 2016; Kitsantas, Baylor and Hiller, 2019). The lack of internal freedom, the ability to think critically can cause the individual entrepreneur be dependent on the circumstances that arise, as well as ineffective behavior. The independence of individual entrepreneurs is the dominant motivation, social and psychological characteristics of self-awareness. Critical thinking helps an entrepreneur feel like a competitive person and a specialist who can manage any circumstances. The empirical criteria of critical thinking and the ability to self-regulate are logic, creativity, analysis, convincing argumentation, independence, reasonableness, interest, free behavior, and acceptance of other people's opinions. The opposite criteria, such as manipulation from the outside, lead to a lack of self-regulation and flexible thinking, as well as the use of meaningful information.

Critical thinking contributes to better interaction with other people, efficiency, and growth in professional activities (Dekker, 2020). Due to the fact that society and the socio-economic environment impose certain norms on the entrepreneur that hinder effective development, critical thinking and selfregulation protect the entrepreneur from the negative influence of the environment.

The problem of critical thinking forming and self-regulation of behavior as a mechanism of independent choice of the direction of self-development is of a professional, social, and economic nature. The unfavorable environment for the Russian entrepreneurs is the reason for the inefficiency of thinking and the lack of self-regulation of behavior. The socio-psychological characteristics of an entrepreneur's personality depend on the style of self-regulation of social behavior and freedom of activity (Altinay et al., 2020). Critical thinking allows the individual to use his full potential and internal sources of psychological self-regulation. With the help of critical thinking, such issues as the effectiveness of activities, adaptation to unfavorable economic and social conditions for the development of domestic entrepreneurship are solved (Mushtavinskaya, 2013). In turn, critical thinking allows the entrepreneur to rely entirely on his own opinion, overcoming grouping thinking (Myers, 2010). An individual entrepreneur with a different type of self-regulation, but capable of critical thinking, shows perseverance, professionalism in any uncertain situation.

\section{Conclusions}

The conducted research allows us to draw the following conclusions:

In the course of the study, we found out that individual entrepreneurs have differences in the level of volitional self-regulation. Group 1 has a high level of volitional self-regulation, these differences are significant, Group 2 has low level of volitional self-regulation.

The correlation analysis showed that the level of critical thinking positively correlates with the indicators of perseverance, self-control, evaluation of results, the level of volitional self-regulation, the level of self-regulation of behavior. The level of volitional self-regulation is positively correlated with perseverance, self-control, and the level of mental abilities. Flexibility is positively correlated with programming. The level of mental ability is positively correlated with the level of volitional self-regulation, 
perseverance, self-control, the level of self-regulation of behavior and the level of critical thinking. There are straight, direct and indirect relationships between critical thinking and the style of self-regulation.

Thus, the higher the level of critical thinking of an individual entrepreneur and such categories as self-control, perseverance, evaluation of results, flexibility, programming, the higher the level of selfcontrol, self-regulation of behavior and, in general, improving the effectiveness of professional activities. The development of critical thinking of an individual entrepreneur contributes to the development of selfregulation.

The recommendations for the formulation of a program for the development of critical thinking in individual entrepreneurs with different styles of self-regulation are in the replacing old goals and attitudes with the new ones. An individual entrepreneur in the process of implementing program methods is aimed at self-improvement and self-development. Knowledge and new skills are acquired in the form of activity, there is a formulation of own goals and a search for ways to achieve them, the desire for objectivity, selfcontrol, the formation of personality, the development of critical, analytical and logical thinking, productive activity, flexibility.

The techniques are the first stage for psychological correction of thinking in entrepreneurs who have an insufficiently productive way of thinking (Von Kortzfleisch, Zerwas and Mokanis, 2013). Based on an empirical study, the formed critical thinking is not characteristic of all respondents, which negatively affects the professional activity of an entrepreneur. The program gave rise to the process of formation of reflexive thinking, the purpose of which is the search for knowledge, independence and creativity. Such programs are presented in modern research (Malik and Ubaidillah, 2020; Peschl, Deng and Larson, 2020).

The following goals and objectives can be achieved with the help of recommendations for the development of the program:

1) to form the skills and abilities of individual entrepreneurs with different types of self-regulation that will help develop critical thinking.

2) to create the necessary conditions for an individual entrepreneur to be able to practice the acquired skills in practice.

3) to use critical thinking in professional activities, taking into account the characteristics of individual, his temperament, attitudes and style of self-regulation.

The goals of the program form a set of professional skills for individual entrepreneurs, which include:

- finding the necessary information related to solving a problem;

- critical comprehension of the received information, their interpretation, immersion in the essence of the phenomena;

- systematization of information according to certain characteristics;

- search and finding of errors in the received information, their correction;

- perception of someone else's point of view, making well-founded arguments;

- maintaining objectivity, calmness, despite the circumstances.

Based on the research works of domestic and foreign scientists and psychologists, as well as an empirical study, the information obtained was used in the implementation of recommendations for the preparation of a program for the development of critical thinking. Well-developed critical thinking is an integral part of successful learning, as well as the optimal use of important information in professional activities and life.

During the development of the program recommendations, the most effective strategies, techniques and exercises were used to help the individual entrepreneur develop the skills that became the beginning of the development of critical thinking, as well as the replacement of non-reflexive thinking with effective thinking. With the help of the program, the necessary conditions will be created for an individual entrepreneur to be able to apply the acquired skills in professional activities. The program is designed to use the knowledge and skills of critical thinking in the work, taking into account the peculiarities of psychological self-regulation of behavior, temperament and attitudes.

In the course of the program, the entrepreneur must acquire the skills of reasoned speech, logical, coherent presentation of thoughts, and the use of speech for communicative, motivational, and creative communication.

During the elaboration of the program for the development of critical thinking, a dominating condition was created, which consists in the transfer of specific knowledge, provoking cognition in students, critical comprehension of the proposed material, selection of information by reflexive methods, in terms of its functionality and relevance in practice.

Thus, the successful implementation of the program for the development of critical thinking in individual entrepreneurs with different styles of self-regulation depends on the external conditions, 
psychological mood and faith in the old attitudes and goals.

We see the prospects for further research in the fact that the indicators of self-regulation, mental abilities and the level of critical thinking of male and female entrepreneurs will be compared. We will also compare the results of entrepreneurs from different regions of Russia.

\section{Acknowledgements}

The authors are grateful for the help in collecting data for the study the scientific director of the project Galina A. Molokhina.

\section{Conflict of interests}

The authors declare no conflict of interest.

\section{References}

Al-Shalabi, N. (2015) Critical Thinking Skills: The Recipe for an Overwhelming Success in the $21^{\text {st }}$ Century. International Journal of Humanities and Social Science, 5(8), 102-105. Retrieved from https://studylib.net/doc/10466462/criticalthinking-skills--the-century

Altinay, L., Madanoglu, G. K., Kromidha, E., Nurmagambetova, A., \& Madanoglu, M. (2021). Mental aspects of cultural intelligence and self-creativity of nascent entrepreneurs: The mediating role of emotionality. Journal of Business Research, 131, 793-802. https://doi.org/10.1016/j.jbusres.2020.10.048

Barba-Sánchez, V., \& Atienza-Sahuquillo, C. (2012) Entrepreneurial behavior: Impact of motivation factors on decision to create a new venture. Investigaciones Europeas de Dirección y Economía de la Empresa, 18(2), 132-138. https://doi. org/10.1016/S1135-2523(12)70003-5

Belousova, A., \& Pishchik, V. (2015). Technique of thinking style evaluating. International Journal of Cognitive Research in Science, Engineering and Education, 3(2), 1-8. https://doi.org/10.23947/2334-8496-2015-3-2-1-8

Berglund, J. (2020) After Fukushima: Safety culture and fostering critical thinking. Safety Science, 124, 104613, https://doi. org/10.1016/j.ssci.2020.104613

Bowell, T., Cowan, R., \& Kemp, G. (2019). Critical Thinking: A concise guide (5 $5^{\text {th }}$ ed.). Routledge. https://doi. org/10.4324/9781351243735

Davies, M. \& Barnett, R. (Eds.) (2015), The Palgrave handbook of critical thinking in higher education, New York. Pelgrave Macmillan, 591. https://doi.org/10.1057/9781137378057

Dekker, T. J. (2020) Teaching critical thinking through engagement with multiplicity. Thinking Skills and Creativity, 37, 100701 https://doi.org/10.1016/j.tsc.2020.100701

Dwyer, C. (2017). Index. In Critical Thinking: Conceptual Perspectives and Practical Guidelines (pp. 253-255). Cambridge: Cambridge University Press. https://doi.org/10.1017/9781316537411

Fedorov, A. V. (2007). Развитие медиакомпетентности и критического мышления студентов педагогического вуза [Development of the Media Competence and Critical Thinking of Pedagogical University's Students]. Mосква, Межрегиональная общественная орг. в поддержку программы ЮНЕСКО, Орг. Объединенных Наций по вопросам образования науки и культуры [Moscow, Interregional Public Organization in support of the UNESCO Program, Org. United Nations Educational, Scientific and Cultural Organization], 616. Retrieved from https://search. rsl.ru/ru/record/01003406296 (In Russ.)

Halpern, D. F. (2013). Thought and Knowledge: An Introduction to Critical Thinking (5 th $^{\text {ed. }}$.). New York, NY: Psychology Press. Retrieved from https://tandfbis.s3.amazonaws.com/rt-media/pdf/9781848726291/chpt_1.pdf

Kamgar, N. \& Jadidi, E. (2016) Exploring the Relationship of Iranian EFL Learners Critical Thinking and Self-regulation with their Reading Comprehension Ability. Procedia - Social and Behavioral Sciences, 232, 776-783. https://doi.org/10.1016/j. sbspro.2016.10.105

Karabey, C. N. (2012). Understanding Entrepreneurial Cognition through Thinking Style, Entrepreneurial Alertness and Risk Preference: Do Entrepreneurs differ from others? Procedia - Social and Behavioral Sciences, 58, 861-870. https://doi. org/10.1016/j.sbspro.2012.09.1064

Kerr, S. P., Kerr, W. R. \& Xu, T. (2017). Personality Traits of Entrepreneurs: A Review of Recent Literature. Retrieved. Harvard. Business. School. from https://www.hbs.edu/faculty/Publication\%20Files/18-047_b0074a64-5428-479b-8c8316f2a0e97eb6.pdf

Kitsantas, A., Baylor, A. L. \& Hiller, S. E. (2019). Intelligent technologies to optimize performance: Augmenting cognitive capacity and supporting self-regulation of critical thinking skills in decision-making. Cognitive Systems Research, 58, 387-397, https://doi.org/10.1016/j.cogsys.2019.09.003

Klooster, D. J. (2002). What is Critical Thinking. Political Science. https://doi.org/0.4324/9780203874134

Korzhuev, A. V., Popkov, V. A. \& Ryazanova, E. L. (2001). Как формировать критическое мышление? [How to form critical thinking?]. Высшее образование в России [Higher education in Russia], 5, 55-58. Retrieved from https://www. elibrary.ru/item.asp?id=9568864 (In Russ.)

Lutsenko, E. L. (2014). Адаптация теста критического мышления Л. Старки [Adaptation of the critical thinking test by $L$. Stark]. Вісник Харківського національного університету. Серія «Психологія» [Bulletin of Kharkiv National University. Psychology Series], 1110, 65-70. Retrieved from http://dspace.univer.kharkov.ua/handle/123456789/9999 (In Russ.)

Malik, A., \& Ubaidillah, M. (2020). Students Critical-Creative Thinking Skill: A Multivariate Analysis of Experiments and Gender. International Journal of Cognitive Research in Science, Engineering and Education (IJCRSEE), 8(Special issue), 49- 
58. https://doi.org/10.23947/2334-8496-2020-8-SI-49-58

Morossanova, V. I. (2003). Extraversion and neiroticism: The typical profiles of Self-regulation. Europ. Psychologist, 4, 279_ 288. https://doi.org/10.1027/1016-9040.8.4.279

Morossanova, V. I. (2010). Саморегуляция и индивидуальность человека: [монография] [Self-regulation and human individuality: monograph]; Russian Academy of Sciences, Institute of Psychology, Russian Academy of Sciences. education, Psychological in-t. Moscow: Nauka, 518. Retrieved from https://search.rsl.ru/ru/record/01004886834 (In Russ.)

Myers, D. G. (2010). Intuition: Its Powers and Perils. Psychological Inquiry, 21(4), 371-377. https://doi.org/10.1080/104784 $0 \times .2010 .524469$

Mushtavinskaya, I. V. (2013). Технология развития критического мышления на уроке и в системе подготовки учителя [Technology for the development of critical thinking in the classroom and in the teacher training system]. Saint Petersburg: KARO, 140. Retrieved from https://search.rsl.ru/ru/record/01006699212

Peschl, H., Deng, C. \& Larson, N. (2020). Entrepreneurial thinking: A signature pedagogy for an uncertain $21^{\text {st }}$ century. The International Journal of Management Education, 100427 https://doi.org/10.1016/j.ijme.2020.100427

Popkov, V. A., Korzhuev, A. V. \& Ryazanova, E. L. (2001). Критическое мышление в контексте задач высшего профрессионального образования [Critical thinking in the context of higher professional education tasks]. Mосква: Изд-во МГУ [Moscow, MSU Publishing House]. 166. Retrieved from https://search.rsl.ru/ru/record/01000705120 (In Russ.)

Robert, R. \& Petersen, S. (2013). Critical thinking at the bedside: providing safe passage to patients. Medsurg Nurs., 22(2), 85-118. Retrieved from https://pubmed.ncbi.nlm.nih.gov/23802494/

Smith, E. (2011). Teaching critical reflection. Teaching in Higher Education, 16(2), 211-223. https://doi.org/10.1080/13562517 .2010 .515022

Spiridonov, N. I. (1980). Психическая саморегуляция, движение, здоровье [Mental self-regulation, movement, health]. Ставрополь: Кн. изд-во [Stavropol: Book Publishing House]. 110. Retrieved from https://search.rsl.ru/ru/ record/01001030050 (In Russ.)

Staniewski, M. W. \& Awruk, K. (2019). Entrepreneurial success and achievement motivation - A preliminary report on a validation study of the questionnaire of entrepreneurial success. Journal of Business Research, 101, 433-440. https:// doi.org/10.1016/j.jbusres.2019.01.073

Starkey, L. (2004). Critical thinking skills success. NY: Learning Express, LLC., Retrieved from https://ru.scribd.com/doc/92985/ Critical-Thinking-Skills-Success-in-20-Minutes-a-Day-Lauren-Starkey

Surkova, E. G. (2008). Проективные методы диагностики [Projective methods of diagnostics]. Москва: Аспект Пресс [Moscow: Aspect Press]. 143. Retrieved from https://search.rsl.ru/ru/record/01004045489 (In Russ.)

Swart, R. (2017). Critical thinking instruction and technology enhanced learning from the student perspective: A mixed methods research study. Nurse Education in Practice, 23, 30-39, https://doi.org/10.1016/j.nepr.2017.02.003

Szenes, E. \& Tilakaratna, N. (2021). Deconstructing critical reflection in social work and business: Negotiating emotions and opinions in reflective writing. Journal of English for Academic Purposes, 49, 100931, https://doi.org/10.1016/j. jeap.2020.100931

Tang, T., Vezzani, V. \& Eriksson, V. (2020). Developing critical thinking, collective creativity skills and problem solving through playful design jams. Thinking Skills and Creativity, 37, 100696, https://doi.org/10.1016/j.tsc.2020.100696

Von Kortzfleisch, H. F.O., Zerwas, D. \& Mokanis, I. (2013). Potentials of Entrepreneurial Design Thinking® for ntrepreneurship Education. Procedia - Social and Behavioral Sciences, 106, 2080-2092, https://doi.org/10.1016/j.sbspro.2013.12.237

Yaldı, N. \& Bailey, M. (2019). The Effect of Critical Thinking on Making the Right Decisions in the New Venture Process. Procedia - Computer Science, 158, 2019, 281-286 https://doi.org/10.1016/j.procs.2019.09.053

Zagashev, I. O. \& Zair-Bek, S. I. (2003). Критическое мышление: технология развития [Critical thinking: technology of development]. Санкт-Петербург: Альянс "Дельта" [St. Petersburg: Alliance "Delta"]. 113. Retrieved from https:// bookmix.ru/bookprice.phtml?id=341529 (In Russ.)

Zair-Bek, S. I. \& Mushtavinskaya I. V. (2011). Развитие критического мышления на уроке [Development of critical thinking in the classroom]. Москва: Просвещение [Moscow: Enlightenment]. 222. Retrieved from https://search.rsl.ru/ru/ record/01004885130 (In Russ.) 